\title{
Analisis Sistem Pengendalian Intern Pengajuan Kredit Usaha Rakyat Pada Bank Jateng Cabang Koordinator Magelang
}

\author{
Astrid Prasetyati Cahyani \\ Universitas Tidar \\ astridprasetyati99@gmail.com
}

\section{Chaidir Iswanaji \\ Universitas Tidar \\ chais@untidar.ac.id}

\begin{abstract}
Abstrak
Bank Jateng Cabang Koordinator Magelang merupakan bank yang memberikan kredit usaha rakyat kepada nasabah yang berdomisili di Jawa Tengah. Kegagalan kredit dapat disebabkan oleh kurangnya pengawasan pengendalian intern dan bank harus mampu melakukan pengendalian intern untuk meminimalkan risiko kredit dalam hal pemberian kredit. Penelitian ini bertujuan untuk mengetahui dan menganalisis sistem pengendalian internal pada aplikasi Kredit Usaha Rakyat (KUR) Bank Jateng di Cabang Koordinator Magelang. Metode yang digunakan dalam penelitian ini adalah metode penelitian deskriptif dengan menggunakan teknik wawancara dan kepustakaan. Fokus penelitian ini adalah untuk memberikan struktur organisasi dan prosedur Kredit Usaha Rakyat pada Bank Jateng Cabang Koordinator Magelang. Dari hasil penelitian terlihat bahwa struktur organisasi Bank Jateng meliputi analis perkreditan, departemen hukum dan manajemen perkreditan, serta memiliki tanggung jawab masing-masing dalam pelaksanaan perkreditan. Bank Jateng Cabang Koordinator Magelang tidak memiliki tanggung jawab dan wewenang yang tumpang tindih, dan setiap departemen mampu menjalankan tugasnya. Dalam penelitian ini dapat diketahui bahwa untuk mendukung pengendalian internal, perlu dicermati bidang-bidang yang perlu ditingkatkan dalam proses pemberian Kredit Usaha Rakyat agar pengendalian internal dapat terlaksana dengan baik. Hal terkait kesediaan nasabah untuk membayar dalam mengembalikan pinjaman dan kesediaan nasabah dalam pembayaran bunganya perlu diperhatikan oleh bank, pengendalian intern perlu didukung dengan menyediakan prosedur yang perlu diperbaiki atau perlu ditingkatkan, Kredit Usaha Rakyat yang diberikan Bank Jawa Tengah bersifat spesifik dimana nasabah Bank Jawa Tengah hanya menetap di Jawa Tengah dan memiliki tata cara di Bank Jawa Tengah. Selain itu perlu diperhatikan struktur organisasi dalam memaksimalkan fungsis-fungsi terkait untuk kelancaran operasional.
\end{abstract}

Kata Kunci Deskriptif, KUR, Pengendalian Intern 


\section{PENDAHULUAN}

Bank adalah lembaga keuangan yang bekerja berdasarkan kepercayaan masyarakat, dan kegiatan usahanya adalah menghimpun dana dan menyalurkan dana. Bank berperan serta dalam meningkatkan kesejahteraan masyarakat dengan memberikan layanan perbankan yang dibutuhkan oleh masyarakat. Selain menyimpan uang di bank, masyarakat juga dapat meminjam uang dari bank dalam bentuk kredit untuk memenuhi kebutuhannya.

Kredit adalah instrumen keuangan yang memungkinkan individu atau badan usaha meminjam uang untuk membeli produk dan mengembalikan produk dalam waktu yang telah ditentukan. Kredit ini bisa dalam bentuk kredit konsumen atau kredit usaha pengembangan. Pemerintah memberikan program kredit bagi masyarakat yang memiliki usaha kecil dan akan dikembangkan melalui program Kredit Usaha Rakyat (KUR). Dana penyaluran kepada nasabah dalam bentuk kredit akan menimbulkan risiko tidak dikembalikannya dana yang disalurkan. Untuk meminimalkan risiko tersebut, bank harus melakukan analisis kredit yang tepat.

Tujuan evaluasi kredit adalah untuk menghindari kerugian bank akibat tidak dapat dikembalikannya pinjaman. Diperlukan sistem yang tepat dalam memberikan pinjaman kepada debitur. Sistem ini merupakan bagian dari pengendalian internal dan berfungsi sebagai pedoman dalam pemberian kredit. Pemberian kredit dapat dilaksanakan dengan baik karena sesuai dengan prosedur, dan jika prosedur telah dilaksanakan maka pengendalian intern dapat dilaksanakan dengan baik.

Bank Jateng merupakan salah satu Bank Pembangunan Daerah (BPD) yang menjalankan produk "Kredit Usaha Rakyat" (KUR) kepada masyarakat. Munculnya kredit bermasalah tersebut disebabkan oleh faktor lemahnya pengendalian internal bank, yaitu kurangnya ketelitian pejabat bank dalam menganalisis pengajuan kredit. Selain itu, faktor eksternal berasal dari debitur.

Berdasarkan uraian tersebut dapat disimpulkan bahwa, mengingat kegagalan kredit dapat disebabkan oleh kurangnya pengawasan pengendalian intern, bank harus mampu melakukan pengendalian intern untuk meminimalkan risiko kredit dalam hal pemberian kredit. Berdasarkan latar belakang yang telah diuraikan, maka penulis tertarik untuk mengajukan judul "Analisis Sistem Pengendalian Intern (KUR) pada Permohonan Kredit Usaha Umum pada Koordinator Cabang Magelang Bank Jateng”.

\section{LANDASAN TEORI}

\subsection{Kredit}

Menurut Undang-Undang Perbankan Nomor 10 Tahun 1998, pengertian kredit pada dasarnya adalah cadangan pinjaman yang diberikan bank kepada nasabah, yaitu sejumlah kegiatan usaha yang disepakati bersama dalam jangka waktu yang disepakati antara bank sebagai kreditur dan nasabah sebagai debitur. Ketentuan dalam perjanjian pembiayaan, antara lain meliputi kesediaan debitur untuk mengembalikan kreditnya, termasuk biaya bunga. Menurut Siamat (2006), kredit dibedakan menjadi lima bentuk, yaitu:

1. Klasifikasi pinjaman berdasarkan tanggal jatuh tempo meliputi pinjaman jangka pendek, pinjaman jangka menengah dan pinjaman jangka panjang.

2. Klasifikasi kredit didasarkan pada agunan (collateral), termasuk jaminan kredit (pinjaman terjamin) dan pinjaman tanpa jaminan (unsecured loan). 
3. Klasifikasi kredit didasarkan pada tujuannya, antara lain pinjaman usaha, pinjaman konsumen dan pinjaman produksi.

4. Kredit diklasifikasikan menurut klasifikasinya, antara lain kredit modal kerja dan kredit investasi.

5. Pinjaman non tunai (non cash loan).

\subsection{Pengendalian Kredit}

Pengendalian kredit merupakan penerapan kontrol kredit absolut untuk menghindari kredit macet dan penyelesaian kredit macet. Pengendalian kredit mengacu pada upaya menjaga pinjaman tetap stabil, efektif dan baik (Hasibuan, 2007). Dalam konteks mendorong atau membatasi pertumbuhan ekonomi melalui penggunaan alat moneter yang mempengaruhi kebijakan perkreditan, pengendalian kredit merupakan kebijakan otoritas moneter (kebijakan moneter). Menurut Hasibuan (2007:106), jenis pengendalian kredit adalah:

a. Pengendalian kredit preventif

Pengendalian kredit secara preventif adalah pengendalian kredit yang melakukan tindakan preventif sebelum kredit macet. Pengendalian preventif kredit atau PCC dilakukan dengan cara berikut:

1. Penetapan batas kredit

2. Pemantauan debitur

3. Pelatih debitur

b. Kontrol kredit yang represif

Pengendalian kredit yang represif adalah pengendalian kredit yang dilakukan melalui operasi penagihan / kliring setelah kredit macet. Tegasnya, kredit macet harus diselesaikan dengan menyita jaminan kredit yang relevan untuk membayar kembali pinjaman debitur.

\subsection{Kredit Usaha Rakyat (KUR)}

Kredit Usaha Rakyat (KUR) adalah layanan kredit atau pembiayaan yang diberikan oleh pemerintah melalui bank kepada usaha mikro, kecil, menengah, dan koperasi (UMKMK) atau usaha yang layak tetapi tidak memiliki rekening bank. Dengan kata lain, perseroan masih memiliki potensi atau prospek bisnis yang bagus dan dapat mengembalikan pinjaman tersebut. KUR sendiri mencakup berbagai bentuk usaha, terutama yang bergerak di bidang usaha produktif, seperti pertanian, perindustrian, perikanan dan kelautan, kehutanan hingga usaha jasa simpan pinjam. Semua bentuk bisnis tersebut diharapkan dapat memberikan banyak kemudahan kepada masyarakat.

\subsection{Pengendalian Intern}

Pengendalian internal dapat memiliki arti yang sempit atau luas. Dalam arti sempit, pengawasan internal adalah memeriksa jumlah persimpangan dan pijakan. Secara garis besar, pengendalian internal tidak hanya mencakup inspeksi, tetapi juga semua alat yang digunakan oleh manajemen untuk pengawasan (Baridwan, 2005). Pengendalian internal atau pengendalian internal mengacu pada proses yang dipengaruhi oleh sumber daya manusia dan sistem teknologi informasi untuk membantu organisasi mencapai tujuan tertentu.

\subsection{Tujuan Pengendalian Intern}

Tujuan pengendalian intern menurut (Mulyadi, 2008) adalah sebagai berikut: 

a. Menjaga kekayaan organisasi.
b. Mengecek ketelitian dan keandalan data akuntansi.
c. Mendorong efisiensi.
d. Mendorong dipatuhinya kebijakan manajemen.

\subsection{Unsur-unsur Pengendalian Intern}

Unsur-unsur pengendalian intern menurut (Mulyadi, 2008) adalah sebagai berikut:

a. Struktur organisasi yang memisahkan tanggung jawab fungsional secara tegas.

b. Sistem wewenang dan posedur pencatatan yang memberikan perlindungan yang cukup terhadap kekayaan, utang, dan pendapatan biaya.

c. Praktik yang sehat dalam melaksanakan tugas dan fungsi setiap unit organisasi.

d. Karyawan yang mutunya sesuai dengan tanggung jawabnya.

\section{METODOLOGI PENELITIAN}

3.1. Jenis Studi

Jenis penelitian yang digunakan dalam penelitian ini adalah kualitatif. Penelitian kualitatif adalah penelitian deskriptif dan cenderung menggunakan analisis. Menurut penelitian Suryono (2010), penelitian kualitatif digunakan untuk menyelidiki, menemukan, mendeskripsikan dan menjelaskan kualitas atau ciri-ciri pengaruh sosial yang tidak dapat dijelaskan, diukur atau dideskripsikan dengan metode kuantitatif. Dari segi metode kualitatif, penelitian ini dipisahkan dari data lapangan dan didukung oleh teori-teori yang ada.

\subsection{Metode Penelitian dan Pengumpulan Data}

1) Metode yang digunakan dalam penelitian ini adalah penelitian deskriptif yaitu penelitian yang mendeskripsikan objek penelitian sesuai dengan keadaan aktual saat ini yaitu pada bank Jateng Cabang Magelang. Penelitian deskriptif adalah jenis data statistik yang digunakan untuk menganalisis data dengan cara mendeskripsikan atau mendeskripsikan data yang dikumpulkan tanpa bermaksud untuk membuat kesimpulan atau generalisasi yang umum. (Sugiyono, 2008)

2) Melakukan wawancara, metode penelitian dan pengumpulan data dengan mengajukan pertanyaan dan jawaban secara langsung kepada pihak terkait untuk mendukung penelitian kredit usaha rakyat. Dalam wawancara ini penulis mewawancarai karyawan bagian kredit koordinator cabang Jateng Bank Magelang.

3) Bibliografi, metode pengumpulan data, mengacu pada kutipan jurnal sebelumnya.

\section{HASIL PENELITIAN}

\subsection{Struktur Organisasi}

Setiap perusahaan membutuhkan struktur organisasi, karena dengan adanya struktur organisasi dapat melihat tanggung jawab dan tanggung jawab masing-masing departemen. Berikut ini adalah struktur organisasi Koordinator Cabang Magelang Jawa Tengah seperti terlihat pada Gambar 1. 
JURNAL EKONOMI \& EKONOMI SYARIAH

Jurnal Ekonomi \& Ekonomi Syariah Vol 4 No 1, Januari 2021

E-ISSN : 2599-3410 | P-ISSN : 2614-3259

DOI : https://doi.org/10.36778/jesya.v4i1.359

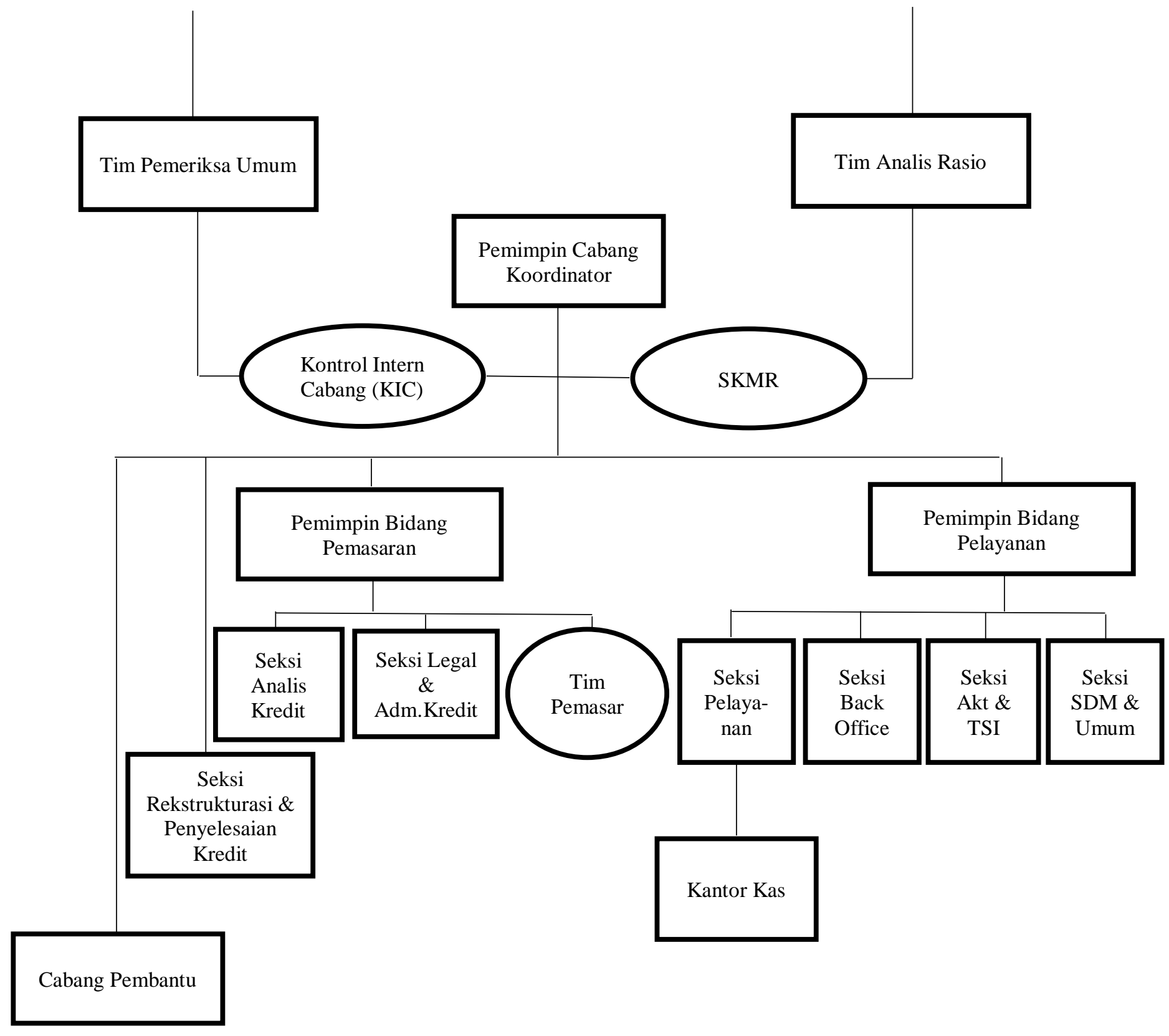

Gambar 4.1 Struktur Organisasi Bank Jateng Cabang Koordinator Magelang

\subsection{Prinsip - prisip Pemberian Kredit}

Ketika bank meminjamkan uang kepada pelanggan, bank mengharapkan uang tersebut dikembalikan. Oleh karena itu, untuk meminimalkan risiko (misalnya non refundable money), bank harus mempertimbangkan beberapa hal terkait creditworthiness (kesediaan untuk membayar) dan kemampuan membayar (ability to pay) nasabah untuk melunasi pinjaman dan bunga saat memberikan kredit. Hal-hal tersebut antara lain kepribadian (personality), ability (ability), capital (permodalan), mortgage (jaminan) dan status ekonomi (economic status), atau biasa disebut dengan 5C. 


\section{a. Character}

Karakteristik, sifat dan kebiasaan debitur (debitur) sangat mempengaruhi pemberian kredit. Kreditor (kreditur) dapat mengecek apakah calon debitur termasuk dalam "Dissatisfied Persons List" (DOT). Oleh karena itu, kreditur juga dapat memeriksa biologi dan informasi mereka sendiri dari lingkungan bisnis. Informasi dalam lingkungan bisnis dapat diperoleh dari pemasok dan pelanggan debitur. Selain itu dapat juga diperoleh dari informasi bank sentral, namun tidak mudah diperoleh masyarakat umum, karena informasi tersebut hanya dapat diakses oleh pegawai bank di bagian perkreditan melalui penggunaan password dan komputer yang terhubung ke bank sentral secara online. Hal ini dapat dilihat dari penilaian kepribadian yaitu memahami latar belakang klien, kebiasaan hidup, gaya hidup dan hal lainnya. Inti dari prinsip karakteristik ini adalah untuk mengevaluasi apakah calon nasabah dapat dipercaya bekerja sama dengan bank. KUR dapat ditawarkan di Bank Jawa Tengah dengan melihat rekening tabungan nasabah untuk melihat transaksi yang telah dilakukan nasabah dan berapa lama waktu yang dibutuhkan nasabah untuk membayar kredit.

\section{b. Capacity}

Kemampuan terkait dengan kemampuan debitur untuk mengembalikan pinjaman. Untuk mengukurnya, kreditur dapat memeriksa kemampuan debitur dalam bidang manajemen, keuangan, pemasaran, dan lainnya.

Evaluasi di Bank Jateng didasarkan pada prinsip kapasitas produksi, antara lain mengecek apakah nasabah pernah mengalami kendala keuangan sebelumnya, mengecek berapa produk yang sudah diproduksi nasabah, dan bagaimana situasi bisnis nasabah. Dan keuntungan yang diperoleh nasabah dengan mengevaluasi kemampuan bank dalam membayar kredit nasabah.

\section{c. Capital}

Dengan melihat modal debitur atau berapa banyak modal yang telah diinvestasikan debitur dalam bisnisnya, kreditur dapat menilai modal debitur. Semakin banyak dana yang diinvestasikan, semakin serius bisnis debiturnya. Berdasarkan karakteristik nasabah bank yang diketahui, selanjutnya dapat memeriksa lebih lanjut laporan keuangan bisnis yang dikelola nasabah sehingga Bank Jawa Tengah dapat menggunakan penilaian ini untuk menentukan apakah nasabah berhak atas pinjaman dan seberapa besar dukungan kredit yang dapat diberikan.

\section{d. Collateral}

Jika debitur tidak dapat melunasi pinjaman, diperlukan jaminan. Biasanya nilai agunan lebih tinggi dari jumlah pinjaman. Bank Jateng memberikan $125 \%$ pinjaman sebagai jaminan. Jika nasabah tidak dapat memenuhi kewajiban pembayaran kembali pinjaman bank, bank dapat menyita aset yang sebelumnya dijanjikan sebagai jaminan. Namun, Bank Jateng tidak secara langsung menjamin standarnya, tetapi memberikan kesempatan kepada nasabah untuk terus menjalankan usahanya dengan harapan nasabah tetap mengutamakan pemenuhan kewajibannya. Agunan yang diberikan nasabah dapat berupa aset tetap berupa tanah, gedung dan mesin.

\section{e. Condition of Economy}

Kondisi ekonomi di sekitar tempat tinggal calon debitur juga perlu dipertimbangkan dengan mempertimbangkan kondisi ekonomi di masa depan. Kondisi ekonomi yang perlu diperhatikan antara lain daya beli masyarakat, ukuran pasar, persaingan, perkembangan teknologi, bahan baku, pasar modal dan masalah lainnya. Kondisi ekonomi suatu wilayah atau negara berdampak besar pada kedua belah pihak, 
termasuk inflasi atau kejadian tak terduga, seperti pandemi Covid-19 yang terjadi di negara-negara di seluruh dunia, termasuk Indonesia yang telah melemahkan perekonomiannya. Oleh karena itu, komunikasi antara nasabah dengan bank sangat penting dilakukan.

\subsection{Prosedur Pemberian Kredit Usaha Rakyat}

Kredit Usaha Rakyat (KUR) adalah kredit/pembiayaan modal kerja dan/atau investasi kepada UMKMK di bidang usaha yang produktif dengan pemberian melalui pola langsung, secara tidak langsung dengan cara executing/channeling dan KUR tersebut dijamin oleh Perusahaan Penjamin. Penerima KUR adalah orang perorangan, badan usaha yang termasuk kepada kriteria Usaha Mikro, Kecil, Menengah, Koperasi, Kelompok Usaha dan Lembaga Linkage lainnya sebagaimana dimaksud dalam pengertian pada peraturan pelaksanaan ini dan memiliki usaha produktif pada semua sektor ekonomi yang tidak melanggar atau bertentangan dengan peraturan perundang-undangan yang berlaku.

1. Permohonan

Berkas permohonan sekurang-kurangnya terdiri dari Surat Permohonan dan dokumen persyaratan permohonan kredit/pembiayaan. Hal-hal yang harus diperhatikan dan dilaksanakan oleh setiap pelaksana kredit dalam hal menerima suatu permohonan kredit adalah:

a. Surat permohonan diajukan secara tertulis oleh calon debitur diantaranya mencantumkan secara jelas tujuan surat, tanggal surat, data calon debitur dan maksud permohonan.

b. Penerimaan permohonan dicatat pada buku registrasi dan diberikan nomor register, serta didisposisi oleh pejabat Bank berwenang untuk tindak lanjut atas surat permohonan tersebut.

c. Hal-hal lainnya agar mempedomani Pedoman Pelaksanaan Kredit (PPK) tentang Proses Persetujuan Kredit dan Dokumentasi dan Administrasi Kredit, atau pedoman pembiayaan syariah.

2. Perjanjian kredit

Penandatanganan perjanjian kredit atau akad pembiayaan berikut seluruh Perjanjian turutannya, dilaksanakan setelah Debitur menandatangani SPPK atau SPPP bermaterai cukup dan telah diserahkan kembali kepada Bank. Dalam hal tertentu menurut pertimbangan Bank seperti nominal kredit yang relative besar dan/atau permasalahan hukum yang relatif kompleks, maka perjanjian kredit atau akad pembiayaan dapat dilakukan secara Notarial Akta. Dokumen perjanjian kredit atau akad pembiayaan minimal dibuat 2 (dua) rangkap: Rangkap pertama untuk Bank, Rangkap kedua untuk debitur dan diserahkan dengan memakai tanda terima.

3. Realisasi kredit

Realisasi kredit dilakukan setelah debitur menandatangani Surat SPPK atau SPPP diatas materai, menandatangani perjanjian kredit atau akad pembiayaan berikut turutannya, melengkapi dokumen yang dipersyaratkan dan membayar biaya sesuai ketentuan yang berlaku. Realisasi kredit dilakukan dengan cara pemindahbukuan ke rekening debitur dengan menggunakan warkat atau bukti cetakan transaksi dari komputer. Terhadap kredit/pembiayaan yang memerlukan penarikan secara bertahap, maka penarikan kredit/pembiayaan diajukan oleh debitur secara tertulis sesuai kebutuhan dan disetujui oleh Bank. 
4. Pembukuan

Proses pembukuan dilakukan oleh petugas bank.

\subsection{Syarat Pengajuan Kredit Produktif}

Untuk mengajukan kredit produktif, perlu memenuhi persyaratan yang ditetapkan oleh bank. Pada Bank Jateng Cabang Koordinator Magelang syarat yang dibutuhkan antara lain:

1. Isi Blangko Permohonan Kredit (dari BPD)

2. Fotocopy KTP (Suami+Istri), Fotocopy KK \& Surat nikah @ 1 lembar

3. Surat Keterangan Kematian / Cerai (jika berstatus Janda/Duda)

4. Fotocopy Jaminan Tambahan

5. Surat Keterangan Usaha dari Desa / Kelurahan

6. Pasfoto Berwarna terbaru 4 x 6 (Suami + Istri) @ 1 lembar

7. Fotocopy NPWP untuk plafon mulai Rp 50.000.000

8. Pembukuan, Nota Pembelian, Nota Penjualan

\subsection{Tabel Angsuran Kredit Usaha Rakyat (KUR) Bank Jateng Magelang}

\begin{tabular}{|c|c|c|c|c|c|}
\hline \multirow{3}{*}{ PLAFOND } & \multicolumn{5}{|c|}{ JANGKA WAKTU KREDIT } \\
\hline & 1 Tahun & 2 Tahun & 3 Tahun & 4 Tahun & 5 Tahun \\
\hline & $\begin{array}{c}12 \\
5.96 \%)\end{array}$ & $\begin{array}{c}24 \\
(589 \%)\end{array}$ & $\begin{array}{c}36 \\
(584 \%)\end{array}$ & $\begin{array}{c}48 \\
(578 \%)\end{array}$ & $\begin{array}{c}60 \\
(573 \%)\end{array}$ \\
\hline 5.000 .000 & 430.240 & 221.355 & 151.747 & 116.921 & 96.038 \\
\hline 10.000 .000 & 860.480 & 442.711 & 303.495 & 233.843 & 192.075 \\
\hline 20.000 .000 & 1.720 .961 & 885.421 & 606.990 & 467.686 & 384.150 \\
\hline 30.000 .000 & 2.581 .441 & 1.328 .132 & 910.485 & 701.529 & 576.225 \\
\hline 40.000.000 & 3.441 .922 & 1.770 .842 & 1.213 .980 & 935.372 & 768.300 \\
\hline 50.000 .000 & 4.302 .402 & 2.213 .553 & 1.517 .475 & 1.169 .215 & 960.375 \\
\hline 60.000 .000 & 5.162 .883 & 2.656 .264 & 1.820 .970 & 1.403 .058 & 1.152 .450 \\
\hline 70.000 .000 & 6.023 .363 & 3.098 .974 & 2.124 .465 & 1.636 .901 & 1.344 .525 \\
\hline 80.000 .000 & 6.883 .844 & 3.541 .685 & 2.427 .960 & 1.870 .744 & 1.536 .600 \\
\hline 90.000 .000 & 7.744 .324 & 3.984 .396 & 2.731 .454 & 2.104 .587 & 1.728 .675 \\
\hline 100.000 .000 & 8.604 .805 & 4.427 .106 & 3.034 .949 & 2.338 .430 & 1.920 .750 \\
\hline 150.000 .000 & 12.907 .207 & 6.640 .659 & 4.552 .424 & 3.507 .644 & 2.881 .126 \\
\hline 200.000 .000 & 17.209 .609 & 8.854 .212 & 6.069 .899 & 4.676 .859 & 3.841 .501 \\
\hline 250.000 .000 & 21.512 .011 & 11.067 .765 & 7.587 .373 & 5.846 .074 & 4.801 .876 \\
\hline 300.000 .000 & 25.814 .414 & 13.281 .318 & 9.104 .848 & 7.015 .289 & 5.762 .251 \\
\hline 350.000 .000 & 30.116 .816 & 15.494 .871 & 10.622 .323 & 8.184 .504 & 6.722 .626 \\
\hline 400.000 .000 & 34.419 .218 & 17.708 .425 & 12.139 .798 & 9.353 .719 & 7.683 .002 \\
\hline 450.000 .000 & 38.721 .620 & 19.921 .978 & 13.657 .272 & 10.522 .933 & 8.643 .377 \\
\hline 500.000 .000 & 43.024 .023 & 22.135 .531 & 15.174 .747 & 11.692 .148 & 9.603 .752 \\
\hline
\end{tabular}

Berdasarkan penjelasan yang penulis dapatkan, jumlah nominal pada plafond 5.000.000 - 50.000.000 merupakan KUR usaha mikro sedangkan plafond $>50.000 .000$ 
merupakan KUR usaha kecil. Jangka waktu 1 tahun sampai 3 tahun diperuntukkan untuk modal kerja sedangkan jangka waktu 4 tahun sampai 5 tahun dapat diperuntukkan untuk investasi. KUR yang diberikan Bank Jateng dikhususkan dan hanya dapat diajukan oleh nasabah Bank Jateng, dimana nasabah Bank Jateng ini hanya yang berdomisili di Provinsi Jawa Tengah.

KUR Bank Jateng berdasarkan informasi yang penulis peroleh dari karyawan bagian kredit Bank Jateng Magelang menyebutkan bahwa terdapat beberapa kelebihan KUR yang dimiliki Bank Jateng diantaranya kreditnya mudah, mampu menjangkau masyarakat luas, dan nasabah dapat memilih angsuran untuk melakukan kreditnya. Sedangkan untuk kekurangan yang dimiiki KUR Bank Jateng diantaranya tidak dapat membiayai ke semua kalangan karena harus mendapat izin dari kementerian melalui sistem informasi kredit proses.

\subsection{Analisis Struktur Organisasi}

Kelancaran terhadap proses perkreditan dapat ditunjang dengan adanya struktur organisasi terutama pada bagian perkreditan. Pada Bank Jateng Magelang memiliki struktur organisasi yang cukup baik, dapat dilihat dari pembagian tugas yang jelas sehingga tidak menimbulkan perangkapan fungsi pada beberapa bagian. Perangkapan fungsi dapat melemahkan pengendalian intern dan penyalahgunaan wewenang dalam pelaksanaan tugas. Struktur organisasi Bank Jateng terdapat analis kredit, bagian legal dan administrasi kredit yang memiliki tugas dan tanggung jawabnya masing-masing dalam melaksanakan kredit. Struktur organisasi memaksimalkan fungsi-fungsi yang terkait agar tidak terjadi tumpang tindih tugas dan wewenang. Pembagian tugas dan wewenang dapat terlaksana dengan baik apabila masing-masing bidang mampu melaksanakan tugas sesuai porsinya dengan memperhatikan tanggung jawabnya.

\subsection{Analisis Prosedur Pemberian Kredit Usaha Rakyat}

Prosedur pemberian dukungan KUR untuk pengendalian internal perlu memperhatikan area-area yang perlu ditingkatkan agar pengendalian internal dapat terlaksana dengan baik. Di antaranya, langkah pengendalian internal yang perlu diperhatikan memastikan bahwa nasabah harus memenuhi dan melengkapi persyaratan sebelum dapat mengajukan kredit agar proses kredit berjalan lancar dan tidak memakan waktu lama, serta selalu disediakan formulir untuk memudahkan nasabah dalam melengkapi dokumen pengajuan kredit, formulir ini juga memudahkan departemen layanan pelanggan untuk memeriksa dokumen-dokumen.

\section{KESIMPULAN DAN SARAN}

a) Kesimpulan

Berdasarkan hasil penelitian dan analisis Bank Jateng Magelang dalam pemberian program Kredit Usaha Rakyat (KUR), maka dapat ditarik kesimpulannya adalah dalam memberikan kredit, bank harus mempertimbangkan beberapa hal terkait kesediaan nasabah untuk membayar dan kemampuan nasabah dalam mengembalikan pinjaman dan bunganya. Pengendalian intern perlu didukung dengan menyediakan prosedur yang perlu diperbaiki atau perlu ditingkatkan agar pengendalian intern dapat dilaksanakan dengan baik. Kredit Usaha Rakyat yang diberikan oleh Bank Jawa Tengah bersifat spesifik dan hanya dapat diajukan oleh nasabah Bank Jawa Tengah, dimana nasabah Bank Jawa Tengah hanya menetap di Jawa Tengah dan memiliki tata cara di Bank Jateng. 
Pengendalian intern juga perlu memperhatikan struktur organisasi untuk memaksimalkan fungsi-fungsi yang terkait agar tidak terjadi tumpang tindih tugas dan wewenang yang berguna untuk kelancaran operasional.

b) Saran

Berdasarkan kesimpulan yang sudah dijelaskan di atas maka penulis akan memberikan saran sebagai berikut:

1. Pengendalian intern harus selalu diperhatikan dan diawasi kinerjanya agar pelayanan selalu memberikan kesan terbaik dan menghindari dampak negatif yang mungkin terjadi dalam perusahaan.

2. Objek penelitian hanya dilakukan pada Bank Jateng Magelang, oleh karena itu untuk penelitian selanjutnya sebaiknya dilakukan perbandingan dengan bank daerah lainnya.

\section{DAFTAR PUSTAKA}

Angelica, N., Jaya, H., \& Putra, R. E. (2016). Analisis Sistem Pengendalian Internal Pada Proses Pemberian Kredit di PT. Bank Rakyat Indonesia, Tbk Cabang Batam. Journal Unrika, 132-153.

Band, William. 2011. Kredit Perbankan. Jakarta: Raja Grafindo Persada.

Baridwan, Z. (2005). Sistem Akuntansi Penyusunan Prosedur dan Metode. Yogyakarta: BPFE.

Fatwandini, A. Z. (2015). Analisis Pengendalian Intern Pemberian Kredit. Artikel Ilmiah Mahasiswa.

Fatiah, S. D., Darminto, \& NP, M. W. (2014). Analisis Sistem dan Prosedur Pemberian Kredit Usaha Rakyat dalam Rangka Upaya Pengendalian Intern. Jurnal Administrasi Bisnis (JAB).

Fibriyanti, Y. V., \& Wijaya, O. I. (2018). Analisis Sistem Pengendalian Internal Pemberian Kredit Pada PD. BPR Bank Daerah Lamongan. Jurnal Penelitian Ekonomi dan Akuntansi.

Hasibuan, M. S. (2007). Pengantar Perbankan. Jakarta: Raja Grafinfo Persada.

Hosen, M. N. (2013). Analisis Pelaksanaan Kredit Usaha Rakyat (KUR) pada Bank Syariah Mandiri Kantor Cabang Pembantu Nusantara Depok. Jurnal Ekonomi Islam, 155-171.

Israk, M. (2017). Analisis Efektivitas Pemberian Kredit pada PD.BPR.Rokan Hulu Pasir Pengaraian.

Kasmir. 2012. Bank dan Lembaga Keuangan Lainnya. Jakarta: Raja Grafindo Persada.Lubis, P. S. (2018). Sistem Pengendalian Intern Pada Proses Pemberian Kredit Mikro Pada PT. BRI (Persero) Tbk Unit Marendal Medan Sm.Raja. Wahana Inovasi, Volume 7 No.2.

Mulyadi. (2008). Sistem Akuntansi. Jakarta: Salemba Empat.

Nawangsari, Y., \& Putra, I. S. (2016). Analisis Sistem Pengendalian Intern Pemberian Kredit Dalam Menurunkan Tingkat Kredit Macet Pada Koperasi Simpan Pinjam "Kharisma Mitra Karya". Jurnal Kompilek, Vol. 8 No.1.

Prasadhana, D. D. (2017). Analisis Sistem Pengajuan Kredit dan Implementasi Pengendalian Internal Dalam Pemberian Kredit Mikro Usaha Kecil Menengah 
Pada PT. Bank Rakyat Indonesia (Persero), Tbk Unit Banyuatis. e-Journal S1 Ak Universitas Pendidikan Ganesha, Vol: 7 No: 1.

Sawori, R., Morasa, J., \& Tangkuman, S. J. (2018). Analisis Penerapan Sistem Informasi Akuntansi Dalam Menunjang Pengendalian Internal Pembiayaan Kredit Usaha Mikro Pada PT Bank Sulutgo. Jurnal Riset Akuntansi Going Concern, 389-398. Sugiyono. (2008). Metode Penelitian Kuantitatif, Kualitatif dan R\&D. Bandung: Alfabeta. 